\title{
In Situ functionalization of Poly(hydroxyethyl methacrylate) Cryogels with Oligopeptides via $\beta$-Cyclodextrin-Adamantane Complexation for Studying Cell-Instructive Peptide Environment
}

Thai Duong Luong, ${ }^{\dagger}$ Mohamed Zoughaib, ${ }^{\dagger}$ Ruslan Garifullin,* Svetlana Kuznetsova, Mustafa O. Guler, and Timur I. Abdullin*

Cite This: ACS Appl. Bio Mater. 2020, 3, 1116-1128

Read Online

ABSTRACT: Oligopeptides are versatile cell modulators resembling pleiotropic activities of ECM proteins and growth factors. Studying the role of cellinstructive peptide signals within 3D scaffolds, yet poorly known, requires effective approaches to introducing bioactive sequences into appropriate materials. We synthesized RGD and GHK motif based peptides 1 and $\mathbf{2}$ linked to the terminal adamantyl group (Ad) and their fluorescent derivatives $\mathbf{3}$ and $\mathbf{4}$. Poly(hydroxyethyl methacrylate) (pHEMA) cryogels with additional PEG/ $\beta$ cyclodextrin (CD) units were prepared as an inert macroporous scaffold capable to bind the adamantylated peptides via affinity CD-Ad complexation. According to toluidine blue staining, the $\mathrm{CD}$ moieties were effectively and stably incorporated in the pHEMA cryogels at nanomolar amounts per milligram of material. The CD component gradually increased the thickness and swelling ability of the polymer walls of cryogels, resulting in a noticeable

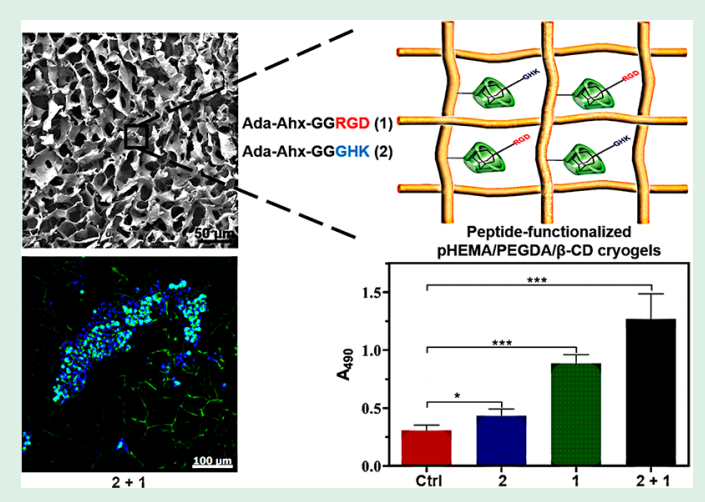
decrease in macropore size and modulation of viscoelastic properties. The labeled peptides exhibited fast kinetics of specific binding to the CD-modified cryogels and were simultaneously immobilized by coincubation. The peptide loading approached ca. $0.31 \mathrm{mg}$ per $\mathrm{cm}^{2}$ of cryogel sheet. A well-defined mitogenic effect of the immobilized peptides $(2<1 \ll 1+2)$ was revealed toward 3T3 and PC-12 cells. The synergistic action of RGD and GHK peptides induced a profound change in cell behavior/morphology attributed to a growth-factor-like activity of the composition. Altogether, our results provide an effective procedure for the preparation of CDmodified pHEMA cryogels and their uniform in situ functionalization with bioactive peptide(s) of interest and an informative study of cellular responses in the functionalized scaffolds.

KEYWORDS: bioactive peptide motifs, extracellular matrix, growth factors, poly(hydroxyethyl methacrylate), cryogels, cyclodextrin-adamantane inclusion complex, RGD, GHK, affinity immobilization, cell responses

\section{INTRODUCTION}

Hydrogel materials (HMs) are versatile soft systems that generally better meet hydration, diffusion, and physical properties of living tissues than solid materials. ${ }^{1}$ HMs therefore have wide biomedical applications, encompassing separation of biocomponents, cell research, tissue engineering, and controlled drug delivery. ${ }^{2-4}$ Biocompatible polymer-based HMs were proved to support mammalian cell growth and be capable of temporarily replacing tissue defects and promote their repair by different mechanisms. ${ }^{3}$

Considerable efforts are being made to impart specific bioactivity to HM-based scaffolds and thus trigger own body responses to repair severe injuries. The use of extracellular matrix (ECM) proteins and/or polysaccharides with natural bioactive motifs is important but not sufficient approach to produce such HMs. Growth factors/cytokines are highly active cell-instructive polypeptides with great potential to treat traumatic and degenerative diseases. ${ }^{5}$ High cost, low stability, and variable properties of recombinant growth factors, however, complicate their combination with HMs. A promising alternative to ECM components and growth factors are synthetic peptides, which benefit from their high purity, safety, stability, and compliance with different chemical modification/immobilization methods. ${ }^{6-8}$ An important strategy to develop the peptides is based on the reproduction of minimal sequences of a natural polypeptide capable of interacting with and modulating mammalian cells. ${ }^{9}$

An extensively studied sequence motif is the RGD tripeptide found in fibronectin and laminin. ${ }^{10,11}$ This peptide is an important cell adhesion ligand involved in cell-matrix

Received: November 19, 2019

Accepted: December 30, 2019

Published: December 30, 2019 
interactions via membrane integrins. ${ }^{11,12}$ RGD was shown to improve attachment and proliferation of adipose-derived stem cells and neurite outgrowth from dorsal root ganglion neurons on the poly- $\varepsilon$-caprolactone-based conduit, ${ }^{13}$ enhance murine fibroblasts spreading on the modified hyaluronic acid hydrogel, ${ }^{14}$ and promote osteogenic differentiation and angiogenic potential of mesenchymal stem cells in alginate hydrogels. ${ }^{10}$

IKVAV, another laminin-derived motif, was reported to stimulate tubulogenesis of vascular endothelial cells in vitro, promote angiogenic effect of the collagen gel in vivo ${ }^{15}$ and also to improve viability/differentiation of neural stem cells encapsulated in the silk fibroin gel. ${ }^{16}$ IKVAV-functionalized self-assembled nanofiber scaffold for brain tissue engineering was developed. ${ }^{17}$ The related cell-binding YIGSR motif enhanced adhesion of preadipocytes, corneal epithelial cells and neurite extension in ganglion explants. ${ }^{18,19}$ Dual peptidepresenting HMs were developed, such as the RGD/YIGSRmodified alginate ${ }^{20}$ and IKVAV/YIGSR-modified collagen materials, ${ }^{21}$ with enhanced ability to support proliferation and differentiation of neuronal and epithelial cells.

The GHK tripeptide, present in type I collagen, osteonectin and other ECM proteins, resembles pleiotropic growth factor activities. GHK modulates skin regeneration by promoting proliferation of fibroblasts and keratinocytes, biosynthesis of ECM component and growth factors, e.g., FGF and VEGF. ${ }^{20-22}$ The copper complex of GHK plays an important role in wound repair, attenuation of skin photodamage, hyperpigmentation and irritation, ${ }^{23}$ chemotaxis of macrophages and mast cells, neurite outgrowth, and angiogenesis. $^{20,21,24}$

The development of effective and reproducible peptidebased HMs requires high stability, uniformity, and availability of the introduced peptide component. Peptides can be immobilized within the hydrogel network by means of physical or chemical entrapment during polymerization. ${ }^{25}$ The process, however, decreases their activity and/or results in rapid elution from the material. Covalent attachment of peptide moieties to preformed $\mathrm{HM}$ via appropriate functional groups ${ }^{26}$ often provides concentration gradients and side products in the modified material. In this regard, affinity methods are much more attractive for peptide immobilization in HM, but they are less elaborated. This type of immobilization generally exploits binding of biotinylated peptides/proteins of interest to different streptavidin (SA)-modified HMs by high-affinity SA-biotin polyvalent interactions. ${ }^{27,28}$ In addition, some affinity of the biotinylated GHK peptide to SA-free collagen scaffold was also reported. ${ }^{29}$ The disadvantages of SA/biotin-based immobilization include limited chemical methods for HM modification with intact SA, its high cost, and potential degradation. Furthermore, the bioeffects of SA and biotin may interfere with bioactive peptide sequences. Hence, more effective methods to produce peptide-functionalized $\mathrm{HM}$ are highly demanded.

In this work, specific $\beta$-cyclodextrin (CD)-adamantane (Ad) complexation ${ }^{30,31}$ was exploited to develop advanced peptide-functionalized HMs. The CD-Ad host-guest system benefits from high stability and inertness of the molecules, their small size, and low cost. ${ }^{32,33}$ Herein, the premodified CD moieties were copolymerized in poly(hydroxyethyl methacrylate) (pHEMA) material, which was selected because of its inert nonproteinaceous structure, and designed in the form of a macroporous cryogel to support bulk diffusion of solutes and cell migration. ${ }^{34}$ The Ada-conjugated GHK and RGD motif- based peptide sequences, namely, Ada-Ahx-GGGHK, AdaAhx-GGRGD, and their fluorescent derivatives, were synthesized. Effective one-step in situ immobilization of the guest adamantylated peptides on the preformed pHEMA cryogels containing the $\mathrm{CD}$ host units was performed. Our results for the first time show that the resulting fully synthetic functionalized materials can be used to reveal individual and combined effects of the peptide signals on mammalian cells within porous HMs.

\section{EXPERIMENTAL SECTION}

2.1. Materials. 2-Hydroxyethyl methacrylate (HEMA), poly(ethylene glycol) diacrylate (PEGDA), $N, N, N^{\prime}, N^{\prime}$ - tetramethylethylenediamine (TEMED), ammonium persulfate (APS), $\beta$-cyclodextrin, acryloyl chloride, toluidine blue O (TBO), Fmoc-Gly-OH, Fmoc$\operatorname{Arg}(\mathrm{Pbf})-\mathrm{OH}$, Fmoc-Asp $(\mathrm{OtBu})-\mathrm{OH}$, Fmoc-His(Trt)-OH, FmocLys(Boc)-OH, Fmoc-Lys(Mtt)-OH, Fmoc-6-aminohexanoic acid (Ahx), 1-adamantaneacetic acid (Ada), 1-pyrenebutyric acid, dansylglycine, Fmoc-Asp(OtBu)-O-Wang resin, Fmoc-Lys(Boc)-OWang, 2-(1H-benzotriazol-1-yl)-1,1,3,3-tetramethyluronium hexafluorophosphate (HBTU), N,N-diisopropylethylamine (DIPEA), triisopropylsilane (TIPS), trifluoroacetic acid (TFA), N,N-dimethylformamide (DMF), and dichloromethane (DCM) were purchased from Sigma-Aldrich, Alfa Aesar, and Novabiochem.

Cell culture media and reagents were purchased from Paneco (Russia). 2-(4-Amidinophenyl)-1H-indole-6-carboxamidine (DAPI) and phenazine methosulfate (PMS) were purchased from SigmaAldrich. 3-(4,5-Dimethylthiazol-2-yl)-5-(3-carboxymethoxyphenyl)-2(4-sulfophenyl)-2H-tetrazolium (MTS reagent) was purchased from Promega. PC-12 and NIH 3T3 cell lines were obtained from the American Type Culture Collection. Cell Tracker Green CMFDA Dye (Thermo Fisher Scientific) and cresyl violet acetate (Acros Organic) were used for cell staining.

2.2. Synthesis of acrylate derivative of $\beta$-cyclodextrin. $\beta$ Cyclodextrin (CD) was modified with acryloyl chloride in aqueous potassium hydroxide $(\mathrm{KOH})$ solution as detailed previously. ${ }^{35}$ The molar ratio of $\mathrm{CD}$ and acryloyl chloride in the reaction solution was maintained at $1: 10$, respectively. The acrylate derivative of $\beta$ cyclodextrin (acryloyl-CD) was isolated by pouring the reaction filtrate into acetone. The structure of acryloyl-CD was analyzed by ${ }^{1} \mathrm{H}$ and ${ }^{13} \mathrm{C}$ NMR spectroscopy (Figure $\mathrm{S} 1$ ). The spectra were recorded on a Bruker Avance-400 NMR spectrometer $\left(400.0 \mathrm{MHz},{ }^{1} \mathrm{H}\right.$; 100.6 $\left.\mathrm{MHz},{ }^{13} \mathrm{C}\right)$. Chemical shifts $(\delta)$ were reported in ppm. ${ }^{1} \mathrm{H}$ NMR $(400$ MHz, DMSO- $\left.d_{6}\right)$ : 3.3-3.4 br. s $\left(\mathrm{H}^{2}, \mathrm{H}^{4}\right)$; 3.5-3.7 br. s $\left(\mathrm{H}^{3}, \mathrm{H}^{5}, \mathrm{H}^{6}\right)$; 3.89 d. d $\left(\mathrm{H}^{2}, 1 \mathrm{H},{ }^{3} J_{\mathrm{HH}} 11.5 \mathrm{~Hz},{ }^{2} J_{\mathrm{HH}} 6.5 \mathrm{~Hz}\right) ; 4.18 \mathrm{~d}$ d $\left(\mathrm{C}^{6} \mathrm{H}^{A}, 1 \mathrm{H}\right.$, $\left.{ }^{3} J_{\mathrm{HH}} 7.8 \mathrm{~Hz},{ }^{2} J_{\mathrm{HH}} 6.5 \mathrm{~Hz}\right) ; 4.5-4.5\left(\mathrm{C}^{6} \mathrm{H}^{B}\right.$, overlapped with $\left.\mathrm{C}^{6} \mathrm{OH}\right)$; $4.39,4.43,4.48$ br. s $\left(\mathrm{C}^{6} \mathrm{OH}\right)$; 4.82 br. s $\left(\mathrm{H}^{1}\right)$; 5.70 br. s $\left(\mathrm{C}^{3} \mathrm{OH}\right)$; 5.76 br. s $\left(\mathrm{C}^{2} \mathrm{OH}\right) ; 5.95 \mathrm{~d}\left(=\mathrm{CH}_{2}{ }^{\mathrm{A}},{ }^{3} J_{\mathrm{HH}} 10.4 \mathrm{~Hz}\right) ; 6.20 \mathrm{~m}(=\mathrm{CH}$, $\left.{ }^{3} J_{\mathrm{HH}} 17.4 \mathrm{~Hz},{ }^{3} J_{\mathrm{HH}} 10.4 \mathrm{~Hz}\right)$; $6.34 \mathrm{~d}\left(=\mathrm{CH}_{2}{ }^{\mathrm{B}},{ }^{3} \mathrm{~J}_{\mathrm{HH}} 17.4 \mathrm{~Hz}\right) \cdot{ }^{13} \mathrm{C}-\left\{{ }^{1} \mathrm{H}\right\}$ NMR (100.6 MHz, DMSO- $\left.d_{6}\right): 165.42 \mathrm{~s}(\mathrm{C}=\mathrm{O}) ; 131.79 \mathrm{~s}(=\mathrm{CH})$; $128.18 \mathrm{~s}\left(=\mathrm{CH}_{2}\right) ; 102.47 \mathrm{~s}\left(\mathrm{C}^{1}\right) ; 101.96 \mathrm{~s}\left(\mathrm{C}^{1}\right) ; 101.63 \mathrm{~s}\left(\mathrm{C}^{1}\right) ; 82.35$ $\mathrm{s}\left(\mathrm{C}^{2}\right)$; 72.06 br. $\mathrm{s}\left(\mathrm{C}^{5}\right)$; $68.84 \mathrm{~s}\left(\mathrm{C}^{2}\right)$; $63.72 \mathrm{~s}\left(\mathrm{C}^{6}\right)$; 59.92 br. $\mathrm{s}\left(\mathrm{C}^{6}\right)$; $59.53 \mathrm{~s}\left(\mathrm{C}^{6}\right)$. In addition, the structure of acryloyl-CD was confirmed by $2 \mathrm{D}$ NMR analysis ( ${ }^{1} \mathrm{H}-\mathrm{COSY}, \mathrm{NOESY}, \mathrm{HMBC}$ and HSQC) as well as by LC-MS (Figure S1).

2.3. Solid-Phase Synthesis of Peptides. Peptides with Cterminal carboxyl group were synthesized on Wang resin by Fmoc solid-phase peptide synthesis method. Fmoc-Asp(OtBu)-O-Wang and Fmoc-Lys(Boc)-O-Wang preloaded resins were used to construct peptide sequences. The resins were swollen in DMF and deprotected using 20\% (v/v) piperidine solution in DMF. Subsequent iterative coupling and deprotection cycles were carried out using 2 equiv. of Fmoc-protected amino acids, 1.98 equiv. of HBTU and 3 equiv of DIPEA in DMF. Following final Fmoc removal, the peptides were modified with Ada, HBTU, and DIPEA (3, 2.98, and 4.5 equiv., respectively). The peptides were cleaved from the resin in cleavage cocktail (95\% TFA, 2.5\% $\mathrm{H}_{2} \mathrm{O}, 2.5 \%$ TIPS). For fluorescence labeling of the peptides, pyrenebutyric acid and dansylglycine were introduced 
via $\varepsilon$-amino group of additional Lys residue after removal of its protecting Mtt (4-methyltrityl) group with 5\% cleavage cocktail in DCM. The cleaved peptides were collected in DCM, which was removed alongside with TFA on a rotary evaporator. Residual viscous material was triturated with ice-cold diethyl ether, and the peptide precipitate was isolated by centrifugation. The precipitate was dissolved in ultrapure water, frozen at $-80^{\circ} \mathrm{C}$, and then lyophilized. The synthesized Ada-Ahx-GGRGD, Ada-Ahx-GGGHK peptides and their fluorescent counterparts Ada-Ahx-GGK(pyrenebutyryl)GRGD and Ada-Ahx-GGK(dansylglycyl)GGHK were purified by preparative HPLC and verified by LC-MS methods. The peptides were analyzed on an Agilent 1200/6530 instrument with electrospray ionization (ESI) source. A Zorbax 300SB-C18 column was used to gradually elute the peptides using acetonitrile $(0.1 \%$ formic acid $) /$ water $(0.1 \%$ formic acid) and acetonitrile $\left(0.1 \% \mathrm{NH}_{4} \mathrm{OH}\right) /$ water $\left(0.1 \% \mathrm{NH}_{4} \mathrm{OH}\right)$ mixed solvents for positively and negatively charged peptides, respectively. The HPLC-MS spectra of the peptides are shown in Figure S4.

2.4. Preparation of Cryogels. pHEMA cryogels were synthesized by the vinyl addition polymerization method in aqueous solution. The concentrations of monomers were presented relative to total mass of all monomers as detailed below (see Table 1). To

Table 1. Monomer Concentration

\begin{tabular}{lcccc} 
monomer & \multicolumn{4}{c}{ concentration $($ wt \%) } \\
HEMA & 78.4 & 78.0 & 76.4 & 73.7 \\
PEGDA & 21.6 & 21.0 & 19.0 & 15.3 \\
acryloyl-CD & 0 & 1.0 & 4.6 & 11.0 \\
\hline
\end{tabular}

synthesize the unmodified cryogel, we mixed HEMA and PEGDA monomers at a final concentration of 3.84 and $0.99 \%(\mathrm{v} / \mathrm{v})$; their relative concentrations were, respectively, 78.4 and $21.6 \%$ of the total mass of the monomers. To prepare the CD-modified cryogels, acryloyl-CD was added to HEMA/PEGDA mixture at a final concentration of $0.05,0.24$ and $0.60 \%(\mathrm{w} / \mathrm{v})$ which corresponded to $1.0,4.6$ and $11.0 \%$ acryloyl-CD content from the mass of all used monomers. The reaction mixtures were purged with $\mathrm{N}_{2}$ followed by addition of $0.40 \%(\mathrm{v} / \mathrm{v})$ TEMED and $0.31 \%(\mathrm{w} / \mathrm{v})$ ammonium persulfate as a free radical-generating system. The resultant reaction solution was carefully stirred and poured into a glass Petri dish as a reactor, which was further placed in a cooling thermostat at a temperature of $-12{ }^{\circ} \mathrm{C}$ for $4 \mathrm{~h}$. It was then transferred into a freezer $\left(-18{ }^{\circ} \mathrm{C}\right)$ and additionally kept for $24 \mathrm{~h}$ to complete polymerization. The product was thawed at room temperature and then carefully washed with water to obtain $3 \mathrm{~mm}$ thick cryogel sheets. The cryogels modified with raw $\mathrm{CD}$ instead of acryloyl-CD were also prepared as reference materials under the same conditions.

2.5. Characterization of CD-Modified PHEMA Cryogels. 2.5.1. Fourier Transform Infrared (FTIR) Spectroscopy. The cryogels were washed with milli- $Q$ grade water and freeze-dried. Attenuated total reflectance (ATR) FTIR spectra of the unmodified and CDmodified pHEMA cryogels were recorded on a Frontier spectrometer (PerkinElmer). The measurements were made in different areas of the materials, and the data were averaged. The spectra were recorded in the wavenumber range of $4000-400 \mathrm{~cm}^{-1}$ with a resolution of 1 $\mathrm{cm}^{-1}$.

2.5.2. Staining with Toluidine Blue. As-prepared hydrated cryogels were cut into square samples $(0.8 \times 0.8 \mathrm{~cm})$ and incubated in $3 \mathrm{~mL}$ of toluidine blue $\mathrm{O}(\mathrm{TBO})$ solution $\left(5 \times 10^{-5} \mathrm{M}, \mathrm{pH} 10\right)$ for $3 \mathrm{~h}$. The samples were washed from weakly bound TBO. The amount of TBO attached to the cryogels was assessed visually and detected by measuring material fluorescence on an Infinite M200 PRO microplate analyzer (Tecan) at $\lambda_{\text {ex }}$ and $\lambda_{\text {em }}$ of 595 and $665 \mathrm{~nm}$, respectively. Temporal stability of the CD moieties in the modified cryogels was investigated after 1, 30 and 60-day incubation of the samples in milli$\mathrm{Q}$ water. After storage, the samples were washed, stained with TBO, and subjected to the same fluorescence analysis.
2.5.3. CD Quantification in Modified Cryogels. The CD-modified cryogels were equilibrated with TBO and washed as described above (in Section 2.5.2). The stained materials were incubated with excess of methanol to release TBO molecules from the complex with $\mathrm{CD}$ moieties. The collected methanol solution of TBO was dried and reconstituted in PBS. The molar amount of released TBO (CD moieties) was determined spectrophotometrically on a on a UV-Vis spectrometer (Lambda 35, PerkinElmer) at $\lambda=665 \mathrm{~nm}$ using a calibration graph for TBO. The estimated $\mathrm{CD}$ amount was normalized per dry mass of the analyzed cryogel samples.

2.5.4. Swelling and Viscoelastic Properties. The cut cryogel samples were equilibrated with milli-Q water. The swelling ratio (SR) was calculated according to the following formula: $\mathrm{SR}=\left(m_{\mathrm{t}}-m_{0}\right) /$ $m_{0} \times 100 \%$, where $m_{\mathrm{t}(1,2)}$ represents the mass of completely swollen cryogels $\left(m_{1}\right)$ or the same materials after removal of weakly bound water (i.e., capillary water, CW) with filter paper $\left(m_{2}\right)$, and $m_{0}$ is the mass of completely dried materials. The volume fraction of $\mathrm{CW}$ relative to the total water volume in the swollen cryogels was calculated by the following formula: $V_{\mathrm{CW}}(\%)=\left(m_{1}-m_{2}\right) /\left(m_{1}-\right.$ $\left.m_{0}\right) \times 100 \%$.

Rheological properties of the swollen cryogels were analyzed on a MCR 302 rotational rheometer (Anton Paar) at $25{ }^{\circ} \mathrm{C}$. The strain sweep and frequency sweep tests were performed by applying $0.01-$ $100 \%$ strain $\left(\omega=10 \mathrm{rad} \mathrm{s}^{-1}\right)$ and $0.01-100 \mathrm{rad} \mathrm{s}^{-1}$ angular frequencies $(\gamma=1 \%)$, respectively. The representative strain and frequency dependencies of the storage $\left(G^{\prime}\right)$ and loss $\left(G^{\prime \prime}\right)$ moduli of the materials were presented.

2.6. Microscopic Analysis of Cryogels. 2.6.1. LSCM of TBOStained Cryogels. The unmodified and CD-containing pHEMA cryogels were cut into square samples $(1 \times 1 \mathrm{~cm})$ and stained in TBO solution $\left(5 \times 10^{-5} \mathrm{M}\right)$ to visualize cryogel microstructure using laser scanning confocal microscopy (LSCM). LSCM images were obtained on a LSM 780 microscope (Carl Zeiss) with $\mathrm{He}-\mathrm{Ne}$ laser excitation $(543 \mathrm{~nm})$. Zeiss ZEN black software was used for acquisition.

2.6.2. Scanning Electron Microscopy. For scanning electron microscopy (SEM), the samples were freeze-dried and coated with 15 $\mathrm{nm}$ conductive layer ( $\mathrm{Au}-\mathrm{Pd}$ alloy) by cathode sputtering on a $\mathrm{Q}$ 150T ES sputter-coater (Quorum Technologies). The SEM analysis was carried out on a high-resolution field-emission scanning electron microscope Merlin (Carl Zeiss) at an accelerating voltage of $5 \mathrm{kV}$ and a probe current of $300 \mathrm{pA}$.

2.7. Binding of Fluorescently Labeled Peptides to CDModified pHEMA Cryogels. The cut samples of the modified cryogel $(4.6 \% \mathrm{CD})$ were placed into a 24 -well plate, covered with Ada-Ahx-GGK(pyrenebutyryl)GRGD peptide solution (0.13-2.62 $\mathrm{mg} / \mathrm{mL}$ ), and incubated at $37{ }^{\circ} \mathrm{C}$ during $3 \mathrm{~h}$ under moderate agitation. The increment of fluorescence intensity of the pyrene probe was monitored every $15 \mathrm{~min}$ on an Infinite M200 PRO microplate analyzer at $\lambda_{\mathrm{ex}}$ and $\lambda_{\mathrm{em}}$ of 339 and $380 \mathrm{~nm}$, respectively. The detected signals were subtracted by fluorescence values of the unmodified cryogel treated with the peptide in the same way. Similarly, CD concentration in the modified cryogels was varied $(1,4.6,11 \%)$ at a constant peptide concentration of $0.36 \mathrm{mg} / \mathrm{mL}$.

To verify the temporal stability of immobilized peptides in the CDmodified cryogels, we stored the peptide-functionalized materials in closed tubes in excess of milli-Q water at a near neutral $\mathrm{pH}(\sim 7)$ in the fridge $\left(4^{\circ} \mathrm{C}\right)$ for $3,7,15$, and 30 days and reanalysed.

To study simultaneous binding of two peptides to the modified cryogels $(4.6 \% \mathrm{CD})$, we treated the samples with Ada-AhxGGK(pyrenebutyryl)GRGD or Ada-Ahx-GGK(dansylglycyl)GGHK $(0.18 \mathrm{mg} / \mathrm{mL})$ as well as with their mixture at the same concentration for each peptide (the total peptide concentration was $0.36 \mathrm{mg} / \mathrm{mL}$ ). The fluorescence intensity of the pyrene- and dansyl-labeled peptides in the samples was measured at $\lambda_{\mathrm{ex}} / \lambda_{\mathrm{em}}$ of $339 / 380 \mathrm{~nm}$ and $339 / 543$ $\mathrm{nm}$, respectively.

2.8. Study of Cell Behavior within Peptide-Functionalized Cryogels. 2.8.1. Cell Growth in Cryogels. PC-12 rat pheochromacytoma cells were maintained in DMEM supplemented with $10 \% \mathrm{HS}$ and $5 \%$ FBS, penicillin $(100 \mathrm{U} / \mathrm{mL}) /$ streptomycin $(100 \mu \mathrm{g} / \mathrm{mL})$ and L-glutamine (2 mM). NIH $3 \mathrm{~T} 3$ mouse embryonic fibroblast cells were 


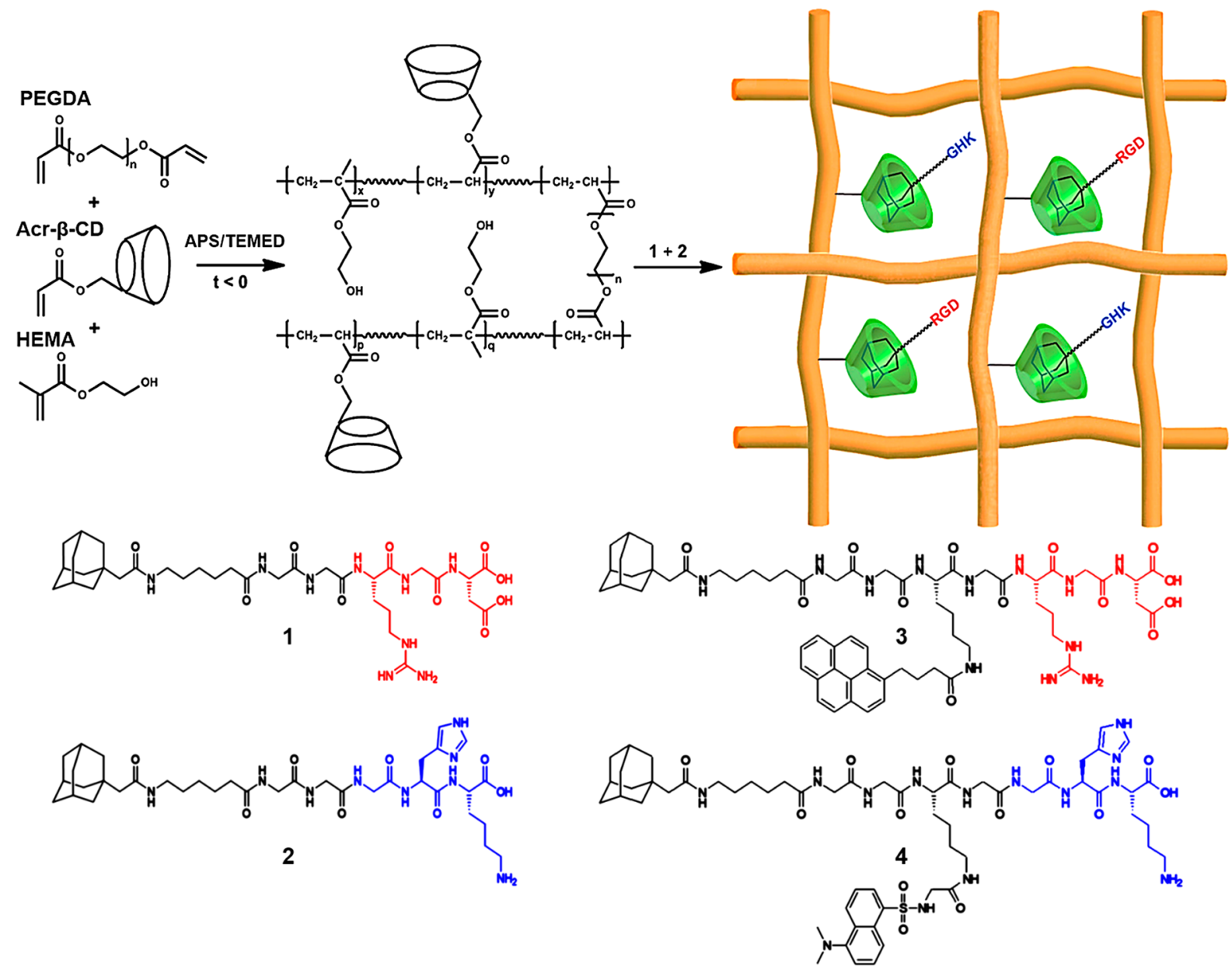

Figure 1. Schematic representation of synthetic peptide-functionalized pHEMA-PEGDA- $\beta$-CD cryogel and chemical structure of its constituents. 2-Hydroxyethyl methacrylate (HEMA), poly(ethylene glycol) diacrylate (PEGDA), monoacrylate ester of $\beta$-cyclodextrin (acryloyl- $\beta$-CD), AdaAhx-GGRGD (1), Ada-Ahx-GGGHK (2), Ada-Ahx-GGK(pyrenebutyryl)GRGD (3), and Ada-Ahx-GGK(dansylglycyl)GGHK (4).

grown in $\alpha$-MEM supplemented with $10 \%$ FBS, penicillin (100 U/ $\mathrm{mL}) /$ streptomycin $(100 \mu \mathrm{g} / \mathrm{mL})$, and L-glutamine $(2 \mathrm{mM})$.

The CD-modified pHEMA cryogels $(4.6 \% \mathrm{CD})$ were cut into disks (14 $\mathrm{mm}$ in diameter, $3 \mathrm{~mm}$ thick) and treated with individual GHK and RGD motif based peptides at a concentration of $0.36 \mathrm{mg} / \mathrm{mL}$ or their composition at a concentration of $0.18 \mathrm{mg} / \mathrm{mL}$ for each peptide (the total peptide concentration was $0.36 \mathrm{mg} / \mathrm{mL}$ ) in PBS for $2 \mathrm{~h}$ for functionalization. The unfunctionalized peptide-free cryogels were used as a reference material. Prior to cell seeding, the samples were incubated in penicillin $(2.5 \mathrm{kU} / \mathrm{mL}) /$ streptomycin $(2.5 \mathrm{mg} / \mathrm{mL})$ in HBSS for $1 \mathrm{~h}$, rinsed, and then equilibrated in the culture medium for another $1 \mathrm{~h}$.

The $3 \mathrm{~T} 3$ and PC-12 cells were seeded on the peptide-functionalized cryogels by the top seeding method in a 24 -well plate. ${ }^{36}$ An aliquot of cell suspension $\left(25 \mu \mathrm{L}, 4 \times 10^{4}\right.$ cells $)$ in low-serum medium (2.5\% FBS, for PC-12 the medium was additionally supplemented with $1 \%$ HS) was dropped on the top of materials. The cryogels with cells were incubated for $1.5 \mathrm{~h}$ at $37{ }^{\circ} \mathrm{C}$ under $5 \% \mathrm{CO}_{2}$ for cell attachment. The cryogels with seeded cells were cultured under standard conditions for 3 days. In addition, the seeding of 3T3 cells was performed by culturing of the cryogels on the top of pregrown cell monolayers for 5 days. ${ }^{36}$ The culture medium was replaced by a fresh one every 2 days.

2.8.2. Cell Detection and Assessment. Proliferation of PC- 12 and 3 T3 cells within the matrices was assessed using the MTS assay. ${ }^{36,37}$ Briefly, the matrices were transferred into new wells of a 24-well plate, rinsed with sterile PBS, covered with $0.5 \mathrm{~mL}$ of a fresh medium supplemented with MTS and PMS, and cultured for $1.5 \mathrm{~h}$. The colored product of MTS reduction by viable cells (formazan) was registered at $490 \mathrm{~nm}$ on an Infinite $200 \mathrm{PRO}$ microplate analyzer. The optical signals were subtracted by the reference signals of the cell-free cryogels kept in the same medium.

For microscopy analysis, the grown cells were stained according to manufacturer's recommendations. Briefly, the matrices were first incubated in culture medium containing CMFDA dye for $1 \mathrm{~h}$ at $37^{\circ} \mathrm{C}$ and then in serum free medium for $30 \mathrm{~min}$. The stained matrices were washed with PBS, fixed in $4 \% p$-formaldehyde solution in PBS, stained with DAPI, and analyzed using LSCM equipped with $448 \mathrm{~nm}$ argon and $405 \mathrm{~nm}$ diode lasers for dual excitation of CMFDA and DAPI, respectively. For bright-field microscopy, the fixed cells were stained with cresyl violet $(0.1 \% \mathrm{w} / \mathrm{v}$ in ultrapure water) for $5 \mathrm{~min}$. The data were presented as a mean \pm SD. Statistical significance between two means was assessed by Student's $t$ test using GraphPad Prism 5.0 software.

\section{RESULTS}

3.1. Cyclodextrin Incorporation in pHEMA Cryogel. pHEMA cryogel with PEGDA $\left(M_{n}=575\right)$ cross-links was used as a cytocompatible $\mathrm{HM}^{38}$ The pHEMA based macroporous cryogel sheets and the Ada-conjugated peptide sequences (14) (Figure 1) were synthesized as detailed in the Experimental Section. To confer affinity properties, the pHEMA cryogels were modified with additional $\beta$-CD monomers capable of binding the adamantylated molecules via host-guest interactions. $^{30}$ For this purpose, acrylate derivative of $\beta$-CD (acryloyl-CD) was obtained by the reaction with acryloyl 
chloride. According to one- $\left({ }^{1} \mathrm{H},{ }^{13} \mathrm{C},{ }^{13} \mathrm{C}-\left\{{ }^{1} \mathrm{H}\right\}\right)$ and twodimensional (COSY, HMBC, HSQS, NOESY) NMR spectroscopy (Figure $\mathrm{S} 1$ ), the product was generally monoacrylate ester of $\beta$-CD at $\mathrm{C}^{6}$ position of the glucopyranose unit. The concentration of acryloyl-CD in the reaction solution was maintained at $1,4.6$ and $11 \%$ of the total mass of all polymerized monomers. In this concentration range, the $\mathrm{CD}$ component did not significantly alter the pHEMA cryogels' appearance.

ATR-FTIR spectra of the CD-modified pHEMA materials and the constituents are summarized in Figure S2. CD derivatization resulted in decrease of the broad band at 3299 $\mathrm{cm}^{-1}$ (stretching vibrations of the $\mathrm{O}-\mathrm{H}$ bond of CD hydroxyl groups), decrease/change of the bands at 1410, 1362, and $1333 \mathrm{~cm}^{-1}$ attributed to the $\mathrm{C}-\mathrm{H}$ bond in $\mathrm{CH}_{2} \mathrm{OH}$ and $\mathrm{CHOH}$ groups, increase of the band at $1019 \mathrm{~cm}^{-1}$ (stretching vibrations of the $\mathrm{C}-\mathrm{O}$ bond), appearance of new bands, e.g. at $1637 \mathrm{~cm}^{-1}$ (stretching vibrations of the $\mathrm{C}=\mathrm{C}$ bond), 936/859 $\mathrm{cm}^{-1}$ (stretching vibrations of the $\mathrm{C}-\mathrm{O}-\mathrm{C}$ bond of the ester group). The changes confirm partial esterification of the $\mathrm{CD}$ hydroxyls with the acrylate groups. FTIR spectrum of pHEMA contained typical bands, e.g. at $3435 \mathrm{~cm}^{-1}$ (stretching vibrations of the $\mathrm{O}-\mathrm{H}$ bond of HEMA hydroxyl group), $2942 / 2879 \mathrm{~cm}^{-1}$ (stretching vibrations of the $\mathrm{C}-\mathrm{H}$ bond of $\mathrm{CH}_{3}, \mathrm{CH}_{2}$ and $\mathrm{CH}$ groups), $1724 \mathrm{~cm}^{-1}$ (stretching vibrations of the ester group), 1149/1072/1023 $\mathrm{cm}^{-1}$ (stretching vibrations of the $\mathrm{C}-\mathrm{O}$ bond in HEMA and $\mathrm{PEG}$ ); the characteristic band of the vinyl group of unreacted monomers (ca. $1650 \mathrm{~cm}^{-1}$ ) was not detected. No new/shifted signals appeared in the spectra of CD-modified pHEMA cryogels in the $\mathrm{CD}$ concentration range used. These data do not reveal noticeable interactions of the polymer chains with the $\mathrm{CD}$ moieties in the cryogels. The variations in the pHEMA band intensities were observed due to a partial replacement of the HEMA/PEG monomers by acryloyl-CD in the materials (Figure S2).

Toluidine blue $\mathrm{O}$ (TBO) dye was used to detect and quantify the $\mathrm{CD}$ moieties in modified cryogels owing to its ability to form an equimolar complex with $\beta$-CD by means of inclusion in the hydrophobic cavity of CD. ${ }^{39}$ The attachment efficiency of TBO molecules to the modified cryogels increased with the concentration of $\mathrm{CD}$ monomers as revealed by both visual (Figure 2A) and fluorescence analysis (Figure 2B) of the materials. The fluorescence signal of stably attached TBO was up to 10 times higher for the cryogels prepared with acryloyl$\mathrm{CD}$ than those with raw CD. This confirms copolymerization of acryloyl-CD with HEMA and PEGDA monomers as a result of vinyl addition polymerization reaction. Residual amounts of the raw $\mathrm{CD}$ detected in the corresponding cryogels (Figure 2B) could be attributed to the $\mathrm{CD}$ molecules nonspecifically captured within the hydrogel network.

According to spectrophotometric quantification of TBO molecules released from the stained cryogels (Section 2.5.3.), the molar content of CD-TBO complex formed in the acryloylCD-modified cryogels was calculated. The corresponding values were $29 \pm 1,129 \pm 8,251 \pm 13$ nmoles of the complex per $10 \mathrm{mg}$ of dry material for the acryloyl-CD concentration of $1,4.6$ and $11 \%$, respectively.

The results suggest almost linear relationship $\left(r^{2}=0.9942\right)$ between the relative amounts of TBO molecules specifically bound to the modified cryogels and $\mathrm{CD}$ monomers in the reaction solution. Hence, the $\mathrm{CD}$ monomers were incorporated into the hydrogel network in proportion to their initial
A

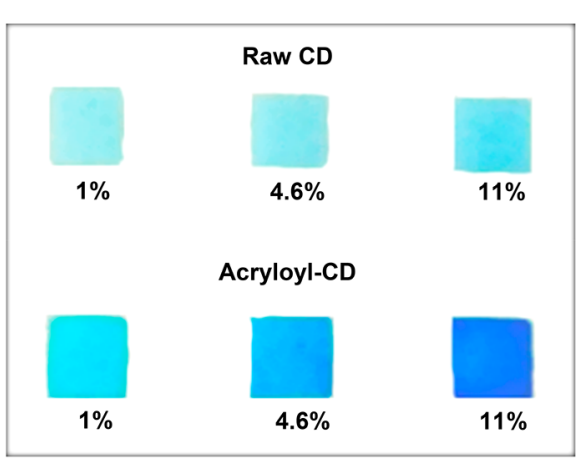

B

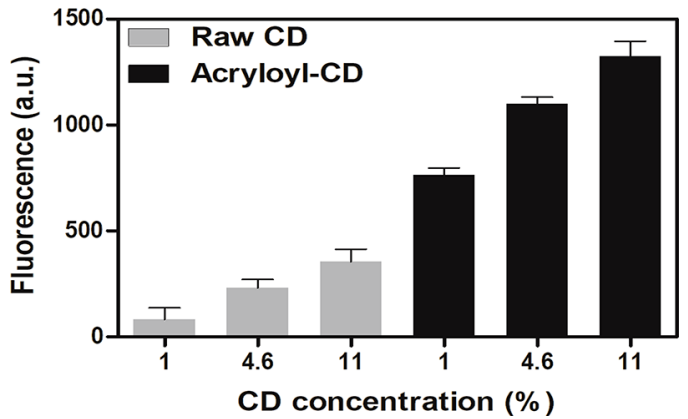

Figure 2. (A) Pictures of pHEMA cryogels modified with raw $\mathrm{CD}$ or acryloyl-CD (concentration is $1,4.6,11 \%$ ) after staining with TBO dye and (B) mean fluorescence intensity of TBO bound to the pHEMA cryogels $\left(\lambda_{\mathrm{ex}} / \lambda_{\mathrm{em}}=595 / 665 \mathrm{~nm}\right)$. The cryogels were stained in $5 \times 10^{-5} \mathrm{M}$ TBO solution ( $\left.\mathrm{pH} 10\right)$; the fluorescence signal of CDfree pHEMA cryogel was subtracted. The data represent the mean \pm $\mathrm{SD}(n=3)$.

concentration. The corresponding incorporation rate of acryloyl-CD in the modified cryogels was approximately 43$57 \%$, further supporting its effective copolymerization under experimental conditions.

The deviation from the above linear relationship upon fluorescence analysis of the same cryogels (Figure 2B) could be explained by diminishing of the TBO fluorescence at increased concentrations of CD-TBO complex in the materials. This is supported by the observation that in the case of raw $\mathrm{CD}$ modified cryogels with lower $\mathrm{CD}$ content, the fluorescence signal showed a linear dependence on the initial CD concentration (Figure 2B).

In addition, the TBO signal was found to be slightly decreased by ca. 1 and $6 \%$ after storage of the acryloyl-CDmodified pHEMA cryogels in aqueous solution for 1 and 2 months, respectively (Figure S5, A), suggesting sufficient temporal/hydrolytic stability of the copolymerized CD units in the materials.

3.2. Microstructure of CD-Modified pHEMA Cryogels. SEM analysis of the freeze-dried cryogels showed that introduction of the acryloyl-CD moieties did not considerably alter pore morphology of the modified materials compared with the CD-free pHEMA material. Increased roughness of the polymer walls, however, was clearly observed in the cryogels modified with $4.6 \% \mathrm{CD}$ and, to a higher extent, with $11 \% \mathrm{CD}$ (Figure $3 \mathrm{~A}$ ). The results suggest that above $1 \%$ concentration the $\mathrm{CD}$ moieties may form a kind of aggregates in the materials. This apparently does not decrease the availability of the $\mathrm{CD}$ rings for complexation with $\mathrm{TBO}$, as supported from the above quantitative analysis. 
A

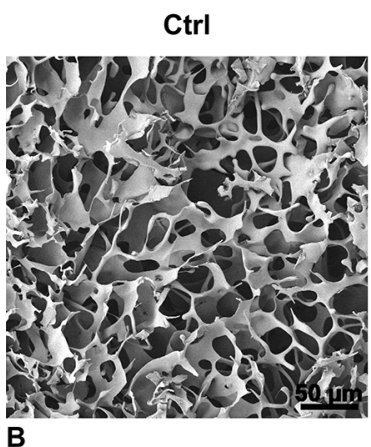

B

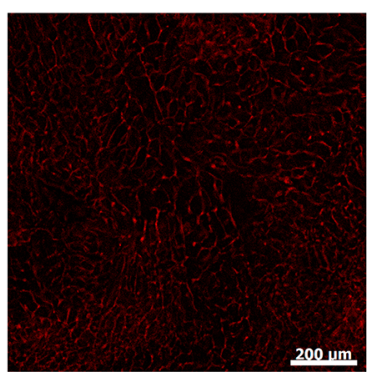

$1.0 \%$
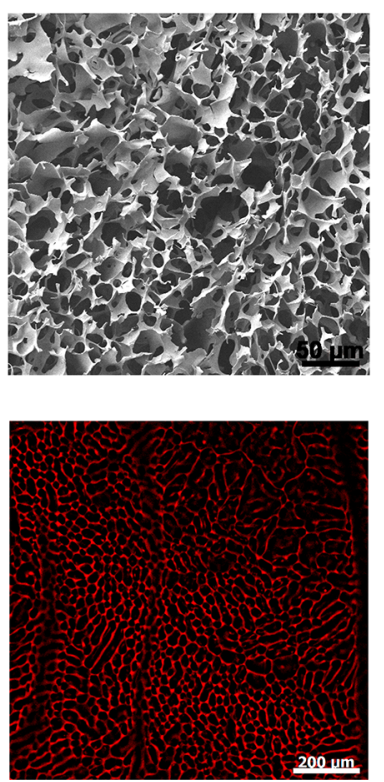

$4.6 \%$
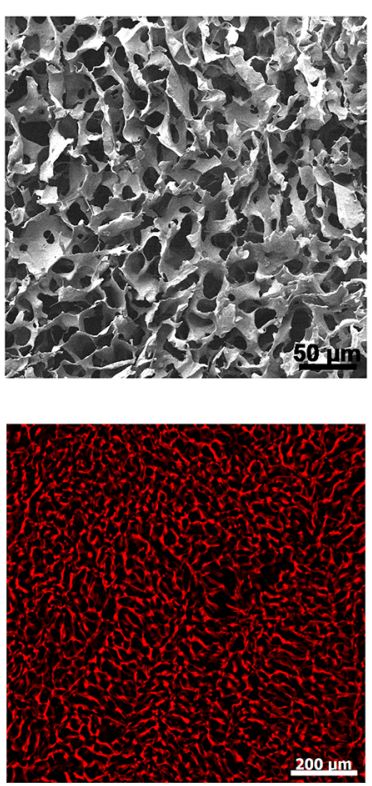

$11.0 \%$
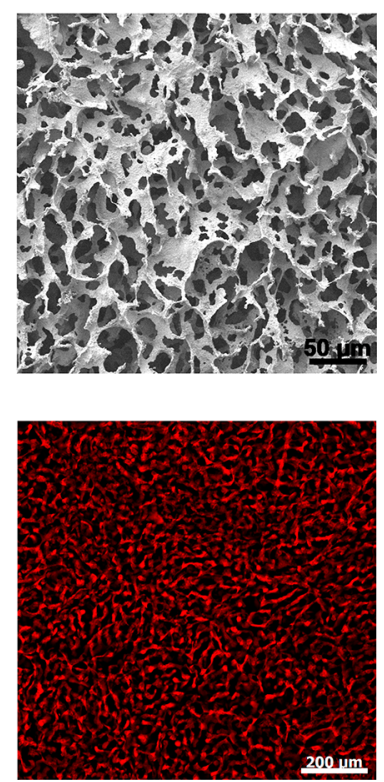

Figure 3. Microscopic visualization of CD-modified pHEMA cryogels: (A) SEM of freeze-dried materials (the upper panel) and (B) LSCM of swollen TBO-stained materials (the lower panel). The initial concentrations of acryloyl-CD used to prepare cryogels (Section 2.4) are shown above the images.

According to LSCM analysis of the swollen materials, the modified cryogel ( $1 \% \mathrm{CD})$ has a well-defined cellular structure similar to that of the reference pHEMA cryogel, though the latter material was weakly stained with TBO and exhibited low fluorescence. At higher CD concentrations, the polymer walls and macropores of the cryogels became somewhat less defined in proportion to the $\mathrm{CD}$ amount (Figure 3B). Altogether, the results show that the $\mathrm{CD}$ component affects microstructure of the polymer network presumably via additional interactions of the $C D$ units, but it does not cause rearrangement of the pHEMA cryogel structure.

3.3. Swelling and Viscoelastic Properties of CDModified pHEMA cryogels. Figure 4 shows the swelling ratio (SR) of the CD-modified cryogels in the form of fully swollen cryogels and the same materials after removal of weakly bound water from macropores (capillary water, CW). The overall SR values of the fully swollen cryogels were found to decrease from 1843 to $1344 \%$ with increase in the CD

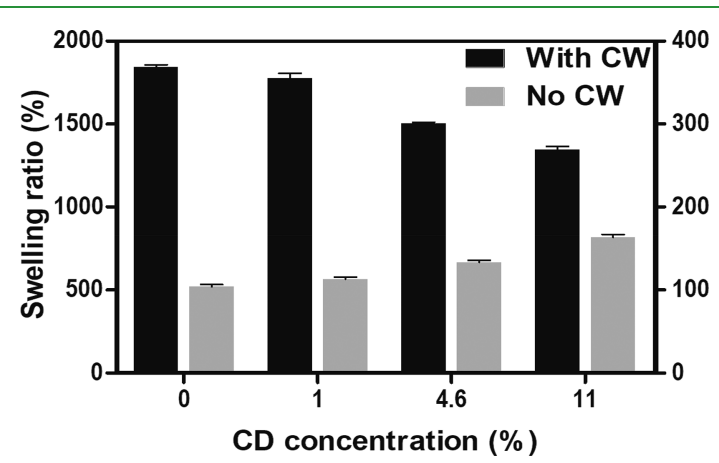

Figure 4. Swelling ratio of CD-modified pHEMA cryogels: completely swollen materials with capillary water (CW) in macropores (left $Y$ axis) and partially swollen materials after $\mathrm{CW}$ removal (right $Y$ axis). The data represent the mean $\pm \mathrm{SD}(n=3)$. concentration from 0 to $11 \%$ (Figure 4, with CW). The materials lacking CW, to the contrary, were characterized by an increase in the SR values from $104 \%$ (no CD) to $163 \%$ (11\% CD) (Figure 4, no CW, $p<0.001$ ), indicating increased water amount in the polymer network containing the $\mathrm{CD}$ moieties.

These data demonstrate that the $\mathrm{CD}$ component in the pHEMA cryogels enhances swelling ability of the polymer walls, and this effect is accompanied by a decrease in CW amount (size of macropores), thus lowering overall swelling of the materials (Figure 4). The relative amount of CW to the total mass of cryogels was reduced from $94.4 \%$ to $87.9 \%$ with an increase in the CD concentration (0-11\%). This CW amount can be assumed to approximate the relative volume content of macropores in the whole cryogels. ${ }^{37}$ The observed swelling behavior of the pHEMA cryogels is in accordance with the microscopy data, which showed enlargement of the polymer walls of the modified materials in proportion to the CD content (Figure 3).

According to the strain sweep test, the synthesized cryogels displayed a linear viscoelastic region at a shear strain amplitude of up to ca. $2 \%$ irrespective of the CD content in the materials (Figure S3, A). According to the frequency sweep test, the materials were characterized by typical viscoelastic properties with prevailing of the elastic component $\left(G^{\prime}\right)$ over the viscous one $\left(G^{\prime \prime}\right)$ by 9-11 times, throughout the entire frequency range, as commonly observed for soft hydrogel systems combining flexibility and mechanical strength. ${ }^{40}$ Furthermore, both moduli exhibited low angular frequency dependency (Figure S3, B), indicating a well-structured hydrogel network in the synthesized cryogels. ${ }^{40}$ The properties of the modified pHEMA cryogels relatively weakly depended on the presence of $\mathrm{CD}$ moieties. There was, however, a tendency to a reproducible increase in $G^{\prime}$ and $G^{\prime \prime}$ moduli of the cryogels with lower $\mathrm{CD}$ content $(1 \%)$ and their decrease at upper $\mathrm{CD}$ content $(11 \%)$ in comparison with the unmodified cryogels (Figure S3, B) from different batches. 
3.4. Functionalization of CD-Modified pHEMA Cryogels with Adamantylated Peptides. Four peptides 1-4 linked with 1-adamantaneacetic acid were designed and synthesized (Figure 1). The bioactive sequences, i.e. RGD and GHK, were separated from the anchor Ada group by spacers composed of aminohexanoic acid (Ahx) and glycine. Additional lysine was included to modify the peptides with pyrenbutyryl and dansylglycyl fluorescent moieties via the side chain amino group (Figure 1).

The peptides were immobilized in the CD-modified pHEMA cryogels by incubating the materials in aqueous peptide solutions in a 24-well plate (Section 2.7.). The time and concentration dependences of binding of the labeled AdaAhx-GGK(pyrenebutyryl)GRGD peptide (3) to the modified cryogel $(4.6 \% \mathrm{CD})$ are provided in Figure $5 \mathrm{~A}$. The data show
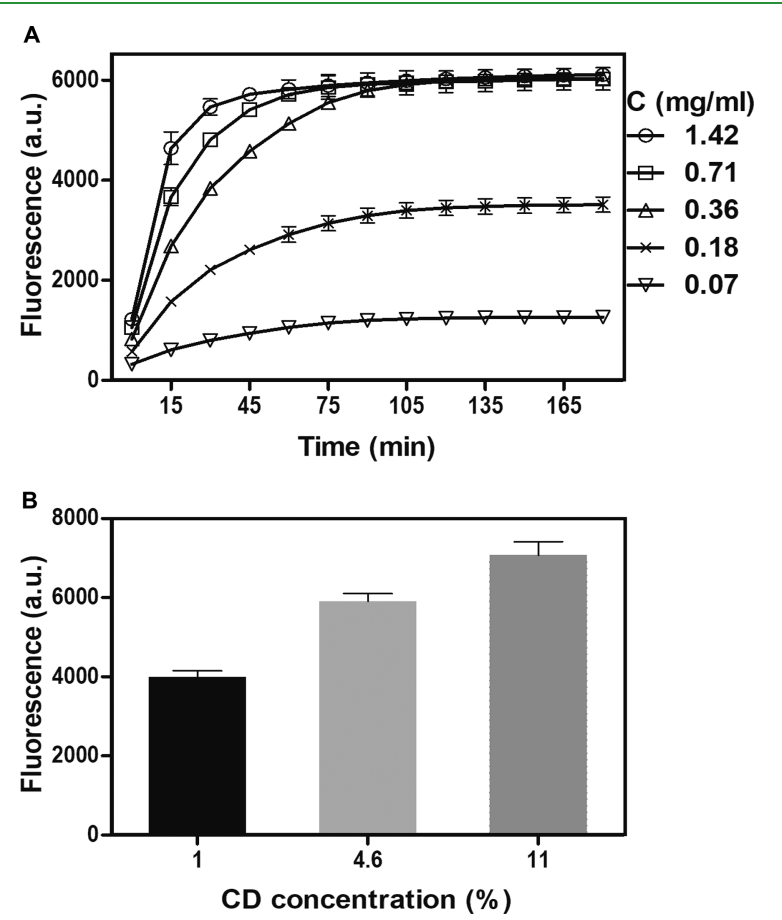

Figure 5. Affinity binding of Ada-Ahx-GGK(pyrenebutyryl)GRGD to CD-modified pHEMA cryogels according to fluorescence analysis. (A) Concentration-dependent kinetics of peptide accumulation in the cryogel $(4.6 \% \mathrm{CD})$. (B) Effect of $\mathrm{CD}$ content in the cryogels on peptide accumulation (peptide concentration is $0.36 \mathrm{mg} / \mathrm{mL}) . \lambda_{\mathrm{ex}} / \lambda_{\mathrm{em}}$ $=339 / 380 \mathrm{~nm}$ (Section 2.7.). The data represent the mean $\pm \operatorname{SD}(n=$ $3)$.

that the pyrene probe fluorescence in the cryogels rapidly grew, indicating fast accumulation of the labeled peptide in the material. The background fluorescence of 3 in the equivalent $\mathrm{CD}$-free cryogel was subtracted to ensure that the binding kinetics resulted from a specific interaction of the adamantylated peptide with the $\mathrm{CD}$ moieties.

The maximum binding rate of 3 to the materials was directly proportional to the peptide amount in solution within the whole concentration range studied $0.07-1.42 \mathrm{mg} / \mathrm{mL}$. The reaction extent at equilibrium was limited by the peptide concentration in the range ca. $\leq 0.18 \mathrm{mg} / \mathrm{mL}$ and reached a plateau at concentrations ca. $\geq 0.36 \mathrm{mg} / \mathrm{mL}$ (Figure 5A).

In addition, the effect of $\mathrm{CD}$ content in the modified cryogels on accumulation of 3 was assessed. The CD-free cryogel exhibited a relatively low background fluorescence of
$1949 \pm 122$ au attributed to nonspecific retention of the peptide within the pHEMA hydrogel. The fluorescence signal of the CD-modified cryogels was 3-5 times higher in proportion to the $\mathrm{CD}$ content. The corresponding subtracted signals upon CD-mediated immobilization of 3 (Figure 5B) had similar dependence on the initial $\mathrm{CD}$ concentration to that observed for TBO binding (Figure 2B). The results indicate that the diffusion process and affinity interaction of the adamantylated peptide $3(\mathrm{MM}=1205)$ in the CD-modified cryogels are not hindered in comparison with thiazine dye molecule $(\mathrm{MM}=306)$.

All CD-modified cryogels treated with 3 effectively preserved their fluorescence upon 1-month storage in aqueous solution with only $2-5 \%$ decrease in their signal (Figure S5, B), demonstrating sufficiently stable immobilization of the adamantylated peptide within the materials.

Simultaneous binding of two labeled peptides, namely 3 and Ada-Ahx-GGK(dansylglycyl)GGHK (4), to the CD-modified cryogel was studied. Well-defined emission spectra of the pyrene and dansyl moieties of the peptides were concurrently detected in the material using the microplate analysis (Figure $6 \mathrm{~A})$. No noticeable decrease in the signals of $\mathbf{3}$ and $\mathbf{4}$ applied
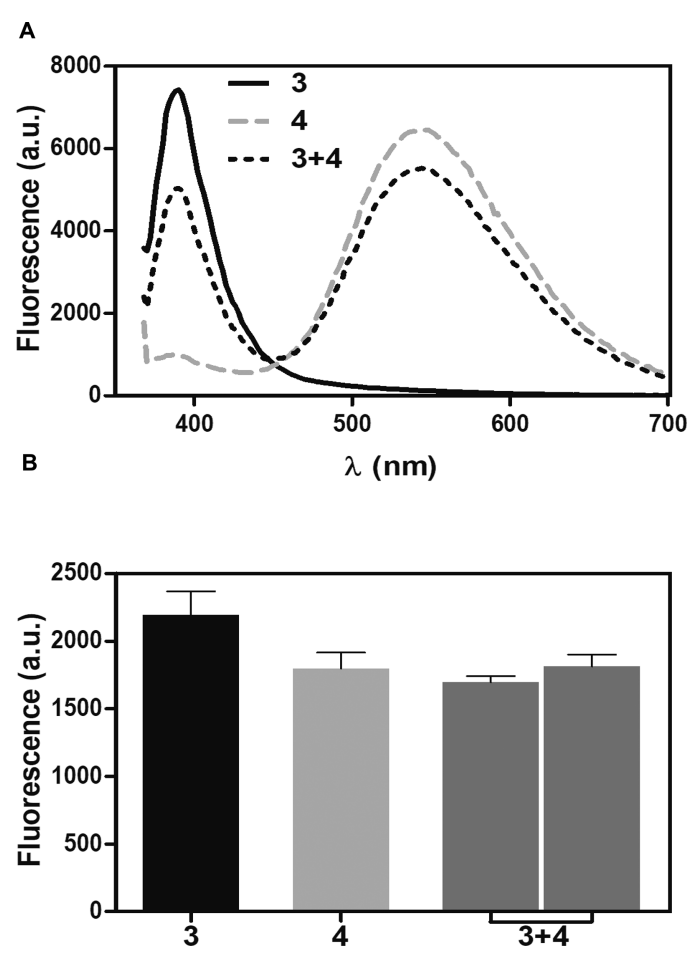

Figure 6. Immobilization of Ada-Ahx-GGK(pyrenebutyryl)GRGD (3), Ada-Ahx-GGK(dansylglycyl)GGHK (4) and their mixture (3 + 4) in CD-modified pHEMA cryogel (4.6\% CD). (A) Emission spectra of the labeled peptides bound to the cryogel. (B) Fluorescence signals of the bound peptides alone and in the mixture. The data represent the mean $\pm \mathrm{SD}(n=3)$. Concentration of each peptide is $0.18 \mathrm{mg} /$ $\mathrm{mL}, \lambda_{\text {ex }}$ is $339 \mathrm{~nm}, \lambda_{\text {em }}$ is 380 and $543 \mathrm{~nm}$ for 3 and 4 , respectively.

together was observed compared with those detected for each peptide alone at the same concentration (Figure 6B). The results demonstrate the feasibility of controllable immobilization of multiple peptides in the modified cryogels to achieve a desired peptide composition in the matrix for in vitro studies.

3.5. Mammalian Cells Behavior in Peptide-Functionalized Cryogels. 3T3 embryo fibroblasts and PC-12 neuronal 
cells were used as model cells responsive to peptide factors. ${ }^{14,41,42}$ The cells were introduced into the peptidefunctionalized pHEMA cryogels by a top-seeding method, and their viability was assessed with the aid of MTS assay. ${ }^{36}$ Figure 7 provides the MTS colorimetric signals generated by the cells

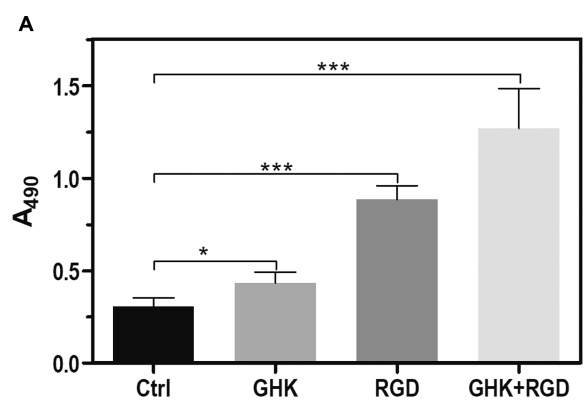

B

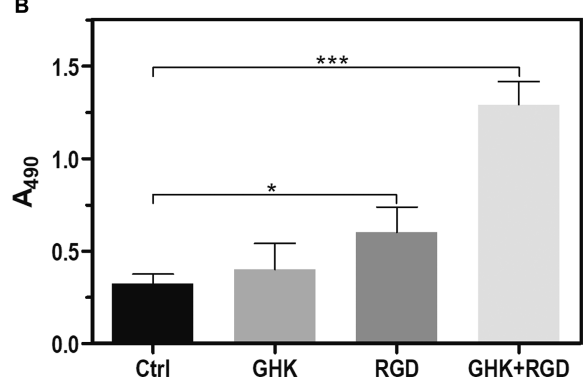

Figure 7. Effect of immobilized RGD and GHK motif-based peptides on viability/proliferation of top-seeded (A) 3T3 cells and (B) PC-12 cells within CD-modified pHEMA cryogel $(4.6 \% \mathrm{CD})$. The MTS assay was performed at day $3(* p<0.05, * * * p<0.001)$. Control (Ctrl) shows the unfunctionalized cryogel. The data represent the mean $\pm \mathrm{SD}(n=3)$.

at 3-day culturing with the cryogels. The modified cryogel (4.6\% CD) supported cell growth (Figure 7, control) similarly to that of the $\mathrm{CD}$-free cryogel (data not shown), indicating that the CD component does not decrease cellular compatibility of the hydrogel material.

The bioactive peptides, GHK or RGD individually, were found to increase the MTS signal, respectively, by 1.41 and 2.88 times for $3 \mathrm{~T} 3$ cells (Figure 7A) and by 1.23 and 1.85 times for PC-12 cells (Figure 7B). LSCM analysis of the CMFDA/DAPI-stained cells also revealed a noticeable increase in the cell number in the RGD-containing matrix over the peptide-free variant (Figure 8). Even much higher MTS signals were detected in the case of the cryogels functionalized with both GHK and RGD peptides with a factor of 4.13 (3T3 cells) and 3.98 (PC-12 cells) compared to the unfunctionalized cryogel (Figure 7 ). This effect of the peptide composition coincided with a great amplification in the number of both types of visualized cells (Figure 8A, B). In addition, massive multicellular associates of $3 \mathrm{~T} 3$ cells were detected in the corresponding matrix (Figure 8A).

To better characterize cell morphology, the matrices were stained with cresyl violet and analyzed by bright-field microscopy. The analysis of PC-12 cells grown in the GHK/ RGD-functionalized cryogel showed the appearance of more spread or elongated cells along with typical compact cells with a round morphology (Figure 8C). The effects of immobilized peptides were reproducible when different cell seeding methods were used. For instance, Figure 9A shows the MTS signals for the peptide-functionalized cryogels cultured on the top of $3 \mathrm{~T} 3$ cell monolayers to allow the fibroblasts to migrate and grow in the matrices. The cell migration was promoted by the immobilized peptides by a factor of 1.52 (GHK), 2.37 (RGD) and 4.82 (GHK+RGD). Furthermore, the microscopy data also confirmed the formation of large multicellular ensembles of $3 \mathrm{~T} 3$ fibroblasts upon interaction with the GHK/RGD-functionalized cryogel (Figure 9B).

\section{DISCUSSION}

Being an almost nontoxic acrylic acid derivative (oral $\mathrm{LD}_{50}>4$ $\mathrm{g} / \mathrm{kg}$ ), 2-hydroxyethyl methacrylate (HEMA) has been widely used to produce inert and biocompatible HMs for tissue engineering and drug delivery applications. Combination of HEMA monomer with PEG derivatives further improves hydrophilicity, mechanical properties and cytocompatibility of the materials. ${ }^{38}$ The modification of HMs with amphipathic cyclodextrins can provide effective binding and controlled release of different lipophilic ligands. ${ }^{43,44}$

In our study, the acrylate derivative of $\beta$ - $\mathrm{CD}$ was covalently incorporated in the pHEMA/PEG cryogels in a concentrationdependent manner during copolymerization, allowing further biofunctionalization of the synthetic materials with the adamantylated peptides $(1-4)$. To detect the CD moieties, we saturated the modified cryogels with $\mathrm{TBO}$ in aqueous solution. The analyzed materials should be stained and washed in an alkaline solution ( $\mathrm{pH} 10)$ to assist inclusion complex formation of deprotonated thiazine molecules with $\beta$-CD rings. ${ }^{45}$ Furthermore, the optical signals of TBO should be corrected against the $\mathrm{CD}$-free cryogel for appropriate quantification of the complexed TBO.

According to LSCM analysis of the stained CD-modified cryogels, no noticeable concentration gradients of TBO were observed along the material sections (data not shown). This confirms that the cryogels support bulk diffusion and complexation of TBO molecules in accordance with evidence that the interconnected macroporous structure of cryogel materials enables almost unhindered diffusion of solutes. ${ }^{34,36}$

The CD-modified cryogels preserved the macroporous structure (Figure 3). At lower concentration (1\%) the CD component induced certain structuration of the macropore system of the swollen cryogel, whereas at higher CD concentrations (4.6 and 11\%) noticeable thickening of the polymer walls was observed (Figure 3B).

The modification of pHEMA cryogels was also accompanied by a gradual decrease in their overall SR by up to $500 \%(27 \%$ of the control value) with an increase in the $C D$ content (Figure 4, with CW). This effect suggests that the CD moieties promote the swelling ability of hydrogel component in the materials, resulting in macropore shrinking and partial extrusion of CW in agreement with the LSCM data (Figure 3B). The increased swelling of the polymer walls could result from the formation of more advanced polymer network with the participation of introduced CD units as well as enhanced hydration capacity of the CD hydroxyls. The latter process seems to mainly contribute to a greater ability of water retention by the cryogels, since the monosubstituted acryloylCD (Figure S1) is not expected to produce covalent cross-links between the polymer chains. The effect of additional interactions, e.g., intermolecular hydrogen bonding between the $\mathrm{CD}$ hydroxyls and pHEMA functional groups, however, could not be excluded considering the role of noncovalent 
A

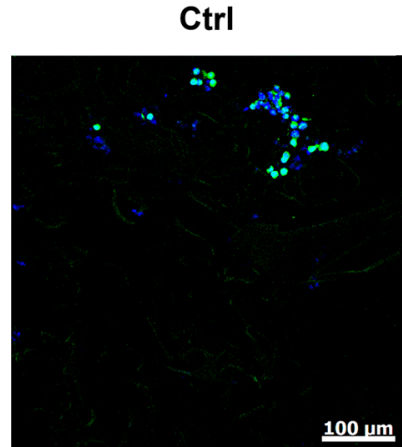

B

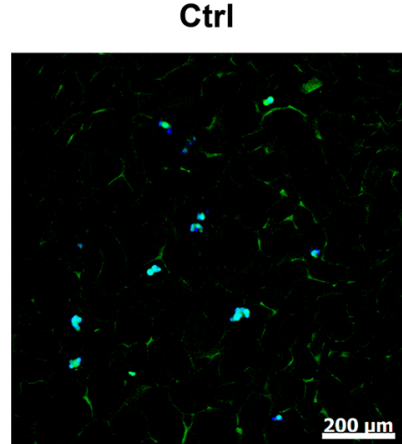

C

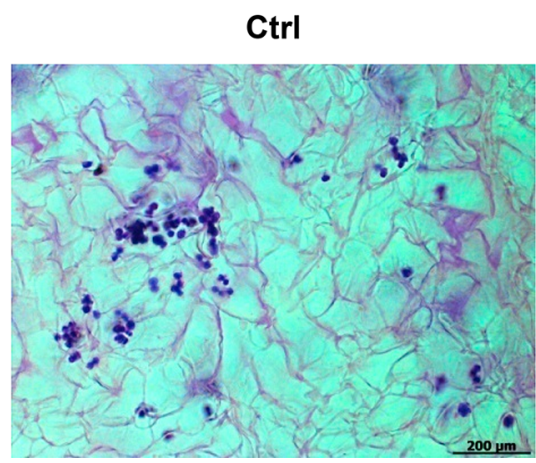

RGD

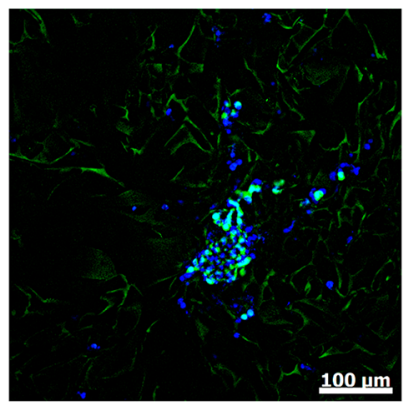

RGD

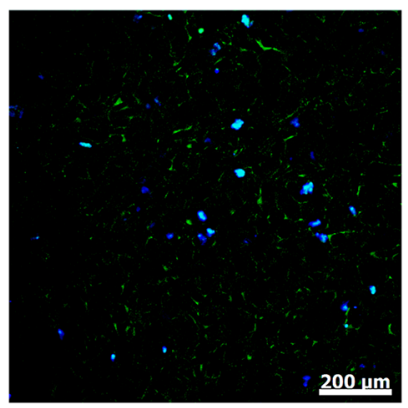

$200.1 \mathrm{~m}$

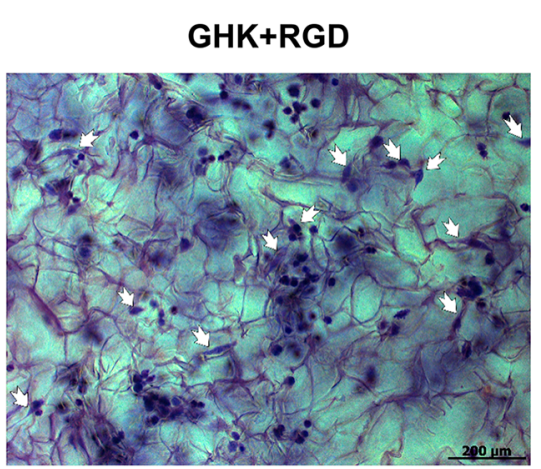

Figure 8. Microscopicvisualization of 3T3 and PC-12 cells grown and fixed in peptide-functionalized cryogels at day 3. A. LSCM of 3T3 cells. B. LSCM of PC-12 cells. C. Bright-field microscopy of PC-12 cells in the peptide-free and RGD/GHK-functionalized cryogels. Arrows indicate some PC-12 cells with distinct morphological changes. The matrices were stained with CMFDA and DAPI (LSCM) or cresyl violet (bright-field microscopy).

metal-mediated interactions in swelling behavior the metaldoped cryogels. ${ }^{37}$

Interestingly, both promoting and decreasing effects of the $\mathrm{CD}$ component on the swelling properties of pHEMA based nonmacroporous hydrogels were previously reported. ${ }^{44,46}$ This could be explained by the concentration dependence of sparingly soluble $\mathrm{CD}$ molecules, which may aggregate at increased concentrations and interfere with the formation of hydrogel network. Our rheological data also suggest that, depending on its used concentration, the $\mathrm{CD}$ component modulates viscoelastic behavior of the pHEMA cryogels with some shift at increased CD content $(>1 \%)$ (Figure S3). This shift can be attributed to an appearance of particulate aggregates on the polymer walls detected in freeze-dried cryogel samples (Figure $3 \mathrm{~A}$ ).

Altogether, our results demonstrate the feasibility of synthesis of the CD-modified pHEMA cryogels in an effective and controllable manner to provide nanomolar amounts of the $\mathrm{CD}$ moieties per mg of dry material. The modification rate is expected to be sufficient for scaffold biofunctionalization with peptides as proved for the cryogel with 4.6\% CD (Figures 7-9). The results, furthermore, do not reveal any impaired availability of the adamanylated peptides for binding to the CD-modified cryogels (Figures 5, 6) compared with TBO (Figure 2B). The acryloyl-CD component itself and its complex with the adamantylated peptide were shown to be stably present in the modified cryogels upon long-term storage (Figure S5), which is a prerequisite for studying the developed materials in vitro.

The Ad group was selected to anchor the RGD and GHK motif-based peptides (Figure 1) to the cryogels because of its relative inertness and high affinity to $\beta$-CD with a binding constant in the range of $1 \times 10^{3}$ to $1 \times 10^{5} \mathrm{M}^{-1} \cdot{ }^{47,48}$ In the synthesized peptides, the Ahx-GG and Ahx-GGK(probe)G spacers were used ${ }^{49,50}$ to ensure availability of the terminal bioactive sequence in the functionalized cryogels and to allow attachment of the fluorescent probes to the $\varepsilon$-amino group of lysine. The low $\beta$-sheet propensity of glycine ${ }^{51}$ was exploited in 


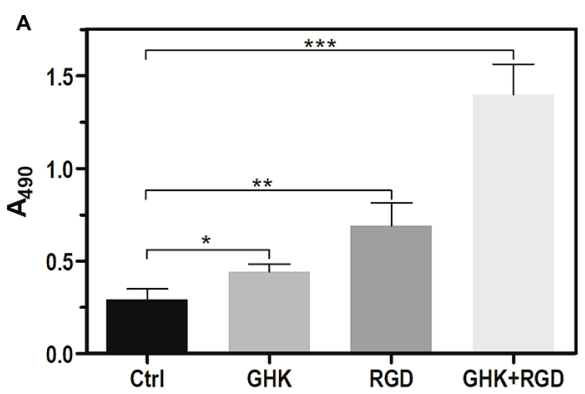

B
Ctrl

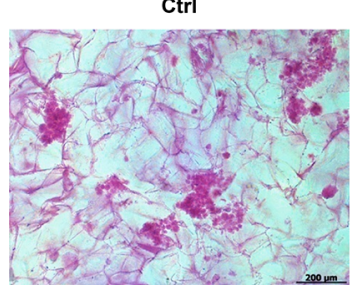

GHK+RGD

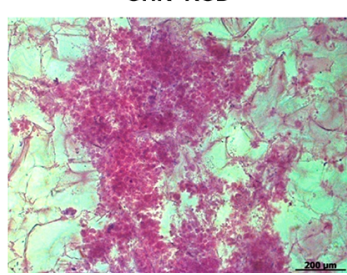

Figure 9. Effect of immobilized RGD and GHK motif based peptides on migration of $3 \mathrm{~T} 3$ cells into CD-modified pHEMA cryogel $(4.6 \%$ $\mathrm{CD})$ cultured on the top of cell monolayers. A. MTS signal of the cells in matrices at day $5(* p<0.05, * * p<0.01, * * * p<0.001)$. The data represent the mean $\pm \mathrm{SD}(n=3)$. B. Corresponding bright-field microscopy images of fixed and cresyl violet-stained cells in the peptide-free (Ctrl) and RGD/GHK-functionalized cryogels (the contact surface is shown).

the spacers to separate the bioactive sequence or the bulky fluorescent probe.

At the excess of 3 in solution, the cryogels became rapidly saturated with the peptide within $1 \mathrm{~h}$ of incubation (Figure $5 \mathrm{~A})$; the amount of immobilized peptide was proportional to the $\mathrm{CD}$ content (Figure 5B). These data suggest effective penetration and binding of the adamantylated peptides to the $\mathrm{CD}$ moieties. Relatively fast kinetics of the process (Figure 5A) indicates effective bulk diffusion of the peptide molecules in cryogel sheets, which could not be expected in the case of nonmacroporous hydrogels.

The loading of cryogels with the bioactive peptides can be adjusted by varying either the peptide concentration in solution (Figure $5 \mathrm{~A}$ ) or the $\mathrm{CD}$ content in the materials (Figure 5B). If an adamantylated peptide is present in deficiency (e.g., $\leq 0.18 \mathrm{mg} / \mathrm{mL}$ ), most of the dissolved molecules are expected to be affinity-bound to the CD moieties after reaching the equilibrium (ca. $100 \mathrm{~min}$, Figure 5A). This allows us to estimate the amount of immobilized peptide per material area/mass in the concentration range and at higher concentrations (by comparing the fluorescence intensity). The calculated bulk loading of 3 peptide in the modified cryogel $(4.6 \% \mathrm{CD})$ was approximately up to $0.31 \pm$ $0.01 \mathrm{mg}$ per $\mathrm{cm}^{2}$ of geometry area of the cryogel sheet at saturation. Picomolar surface concentrations (per $\mathrm{cm}^{2}$ ) of RGD-containing sequences immobilized on synthetic hydrogel and nanofiber biomaterials were reported. ${ }^{52,53}$ Photopolymerization of acryloyl-PEG-RGDS peptide derivative on preformed PEG hydrogel film provided spatially controlled surface immobilization of the peptide in microgram amounts. ${ }^{54}$

In addition, the simultaneous introduction of two adamantylated peptides 3 and $\mathbf{4}$ into the materials was achieved as a result of coincubation (Figure 6). Considering affinity interactions, the final ratio/loading of multiple peptides in the materials can be adjusted by binding deficient amounts of the peptides from appropriate mixture. The results show the feasibility of in situ preparation of biofunctionalized HEMA cryogels presenting required peptide composition by a singlestep and reagent-free incubation of the CD-modified materials in the solution of adamantylated peptides. An inert polymer base of the synthetic cryogels should not interfere with the peptide component, favoring the study of specific cell responses. The CD-Ad affinity complex itself lacks bioactive signals and is much less susceptible to biodegradation than biotin-streptavidin couple. Compared with the developed procedure, other peptide immobilization techniques in HMs, e.g., those based on the entrapment in polymerized hydrogels and/or chemical attachment to preformed materials, ${ }^{25,26,55}$ may compromise loading, stability, and activity of the peptide molecules.

The methods for seeding and quantification of mammalian cells within cryogel matrices were previously compared and optimized. ${ }^{14,36,37} 3 \mathrm{~T} 3$ murine teratoma-derived fibroblasts and rat pheochromocytoma-derived $\mathrm{PC}-12$ cells with inducible neuronal phenotype were studied. These cells are sensitive to different soluble and surface-bound peptide signals including growth factors and ECM-derived ligands, and therefore they are useful models for the evaluation of different cellular responses to biofunctionalized HMs. ${ }^{42,56}$ The $3 \mathrm{~T} 3$ and PC-12 cells compared to each other similarly responded to the immobilized peptides 1 (RGD), 2 (GHK), and their mixture according to both top-seeding ( $\mathrm{ca} .26 \times 10^{3}$ cells per $\mathrm{cm}^{2}$ ) and cell migration methods (Figures 7-9). Low-serum medium (2.5\% FBS) was used to enhance cell responsiveness to the peptides. RGD peptide stimulated cell proliferation more effectively than GHK peptide by 1.5-2 times, and its effect was up to 1.6 times higher for $3 \mathrm{~T} 3$ fibroblasts than PC-12 cells (Figure 7). The results apparently reflect the critical role of RGD motif in cell adhesion/migration processes. ${ }^{11,13,57}$

A synergistic action of RGD and GHK peptides on cell behavior in the HM was for the first time revealed. Specifically, pronounced (ca. 4-4.8-fold) reproducible increase in proliferation of both $3 \mathrm{~T} 3$ and PC-12 cells was detected in the RGD/GHK-functionalized matrix. The combined stimulatory effect of the peptide composition was significantly higher (1.4-2.7 times, $p<0.05)$ than the summed effects of the individual peptides both relative to the peptide-free material. This stimulatory effect was accompanied by an enhancement of intercellular interactions of 3T3 fibroblasts, resulting in the formation of big multicellular ensembles up to $40 \times 10^{3} \mu \mathrm{m}^{2}$ by area (Figure $8 \mathrm{~A}$ ), as well as morphological changes in PC-12 cells (Figure 8C) attributed to probable neuronal differentiation in the presence of RGD/GHK composition. The coimmobilization of RGD with IKVAV or YIGSR peptides on PEG-based hydrogels was earlier reported to promote endothelial cell adhesion and tubulogenesis; the mitogenic effect of the peptides was not compared. ${ }^{57}$ Our results show that the RGD/GHK-functionalized matrix exhibits enhanced stimulatory activity toward mammalian cells, which involves strong mitogenic effect and presumably resembles some other growth factor-like effects related to cell differentiation and altered cell-matrix interactions. The molecular mechanisms underlying cellular responses within the developed peptidefunctionalized pHEMA cryogels will be studied elsewhere. 


\section{CONCLUSIONS}

The synthetic poly(hydroxyethyl methacrylate) cryogels modified with $\beta$-cyclodextrin are useful and effective hydrogel materials, which can be activated with different adamantylated oligopeptides by means of affinity binding. The functionalization can be performed in situ providing controllable/stable loading and high specific activity of the immobilized peptides toward mammalian cells. Our study details the procedure for development and characterization of the peptide-functionalized cryogels on the example of model RGD and GHK motif based sequences. We show the feasibility of establishing specific cellular responses to the immobilized peptide signals in inert three-dimensional environment. The synergistic activity of the RGD and GHK motifs on cell proliferation and behavior was for the first time revealed using the developed materials. The results are of particular interest in different tissue engineering and peptide research areas.

\section{ASSOCIATED CONTENT}

\section{(s) Supporting Information}

The Supporting Information is available free of charge at https://pubs.acs.org/doi/10.1021/acsabm.9b01059.

Figure S1, NMR and LC-MS analyses of the structure of acryloyl-CD; Figure S2, FTIR spectra of the materials; Figure S3, rheological properties of the CD-modified cryogels; Figure S4, LC-MS spectra of the peptides; Figure S5, data on temporal stability of the CD and peptide components in the materials (PDF)

\section{AUTHOR INFORMATION}

\section{Corresponding Authors}

Ruslan Garifullin - Kazan Federal University, Kazan, Russia, and Bilkent University, Ankara, Turkey;

Email: rigarifullin@kpfu.ru

Timur I. Abdullin - Kazan Federal University, Kazan, Russia; (D) orcid.org/0000-0002-3030-3198;

Email: tabdulli@gmail.com, timur.abdullin@kpfu.ru

\section{Other Authors}

Thai Duong Luong - Kazan Federal University, Kazan, Russia

Mohamed Zoughaib - Kazan Federal University, Kazan, Russia; (1) orcid.org/0000-0002-8851-5222

Svetlana Kuznetsova - Kazan Federal University, Kazan, Russia

Mustafa O. Guler - University of Chicago, Chicago,

Illinois; (1) orcid.org/0000-0003-1168-202X

Complete contact information is available at:

https://pubs.acs.org/10.1021/acsabm.9b01059

\section{Author Contributions}

${ }^{\dagger}$ T.D. Luong and M. Zoughaib contributed equally to this article.

Notes

The authors declare no competing financial interest.

\section{ACKNOWLEDGMENTS}

This work was funded by RFBR (Grant 19-03-01010) and performed according to the Russian Government Program of Competitive Growth of Kazan Federal University (KFU). V.V.
Vorobev and Y.N. Osin (Interdisciplinary Center for Analytical Microscopy, KFU), Dr. A.V. Nemtarev (Institute of Chemistry, KFU) is acknowledged for NMR analysis, Dr. I.T. Rakipov and A.A. Akhmadyarov (Institute of Chemistry, KFU) are acknowledged for rheological measurements. Equipment of Interdisciplinary Centre for Shared Use of KFU was used.

\section{REFERENCES}

(1) Zhu, J.; Marchant, R. E. Design properties of hydrogel tissueengineering scaffolds. Expert Rev. Med. Devices 2011, 8 (5), 607.

(2) Tokarev, I.; Minko, S. Stimuli-Responsive Porous Hydrogels at Interfaces for Molecular Filtration, Separation, Controlled Release, and Gating in Capsules and Membranes. Adv. Mater. 2010, 22 (31), 3446.

(3) Nicodemus, G. D.; Bryant, S. J. Cell encapsulation in biodegradable hydrogels for tissue engineering applications. Tissue Eng., Part B 2008, 14 (2), 149.

(4) Caló, E.; Khutoryanskiy, V. V. Biomedical applications of hydrogels: A review of patents and commercial products. Eur. Polym. J. 2015, 65, 252.

(5) Kawaguchi, H.; Oka, H.; Jingushi, S.; Izumi, T.; Fukunaga, M.; Sato, K.; Matsushita, T.; Nakamura, K. A local application of recombinant human fibroblast growth factor 2 for tibial shaft fractures: A randomized, placebo-controlled trial. J. Bone Miner. Res. 2010, 25 (12), 2735.

(6) Loo, Y.; Goktas, M.; Tekinay, A. B.; Guler, M. O.; Hauser, C. A. E.; Mitraki, A. Self-Assembled Proteins and Peptides as Scaffolds for Tissue Regeneration. Adv. Healthcare Mater. 2015, 4 (16), 2557.

(7) Gomes, A.; Teixeira, C.; Ferraz, R.; Prudencio, C.; Gomes, P. Wound-Healing Peptides for Treatment of Chronic Diabetic Foot Ulcers and Other Infected Skin Injuries. Molecules 2017, 22 (10), 1743.

(8) Vlieghe, P.; Lisowski, V.; Martinez, J.; Khrestchatisky, M. Synthetic therapeutic peptides: science and market. Drug Discovery Today 2010, 15 (1-2), 40.

(9) Rahmany, M. B.; Van Dyke, M. Biomimetic approaches to modulate cellular adhesion in biomaterials: A review. Acta Biomater. 2013, 9 (3), 5431.

(10) Ho, S. S.; Murphy, K. C.; Binder, B. Y.; Vissers, C. B.; Leach, J. K. Increased Survival and Function of Mesenchymal Stem Cell Spheroids Entrapped in Instructive Alginate Hydrogels. Stem Cells Transl. Med. 2016, 5 (6), 773.

(11) Studenovska, H.; Vodicka, P.; Proks, V.; Hlucilova, J.; Motlik, J.; Rypacek, F. Synthetic poly(amino acid) hydrogels with incorporated cell-adhesion peptides for tissue engineering. J. Tissue Eng. Regener. Med. 2010, 4 (6), 454.

(12) Seo, J. H.; Kakinoki, S.; Inoue, Y.; Yamaoka, T.; Ishihara, K.; Yui, N. Inducing rapid cellular response on RGD-binding threaded macromolecular surfaces. J. Am. Chem. Soc. 2013, 135 (15), 5513.

(13) de Luca, A. C.; Faroni, A.; Downes, S.; Terenghi, G. Differentiated adipose-derived stem cells act synergistically with RGD-modified surfaces to improve neurite outgrowth in a co-culture model. J. Tissue Eng. Regener. Med. 2016, 10 (8), 647.

(14) Shu, X. Z.; Ghosh, K.; Liu, Y.; Palumbo, F. S.; Luo, Y.; Clark, R. A.; Prestwich, G. D. Attachment and spreading of fibroblasts on an RGD peptide-modified injectable hyaluronan hydrogel. J. Biomed. Mater. Res. 2004, 68A (2), 365.

(15) Nakamura, M.; Mie, M.; Mihara, H.; Nakamura, M.; Kobatake, E. Construction of multi-functional extracellular matrix proteins that promote tube formation of endothelial cells. Biomaterials 2008, 29 (20), 2977.

(16) Sun, W.; Incitti, T.; Migliaresi, C.; Quattrone, A.; Casarosa, S.; Motta, A. Viability and neuronal differentiation of neural stem cells encapsulated in silk fibroin hydrogel functionalized with an IKVAV peptide. J. Tissue Eng. Regener. Med. 2017, 11 (5), 1532.

(17) Sever, M.; Turkyilmaz, M.; Sevinc, C.; Cakir, A.; Ocalan, B.; Cansev, M.; Guler, M. O.; Tekinay, A. B. Regenerative effects of 
peptide nanofibers in an experimental model of Parkinson's disease. Acta Biomater. 2016, 46, 79.

(18) Patel, P. N.; Gobin, A. S.; West, J. L.; Patrick, C. W., Jr Poly(ethylene glycol) hydrogel system supports preadipocyte viability, adhesion, and proliferation. Tissue Eng. 2005, 11 (9-10), 1498.

(19) Duan, X.; McLaughlin, C.; Griffith, M.; Sheardown, H. Biofunctionalization of collagen for improved biological response: scaffolds for corneal tissue engineering. Biomaterials 2007, 28 (1), 78.

(20) Pickart, L.; Vasquez-Soltero, J. M.; Margolina, A. GHK Peptide as a Natural Modulator of Multiple Cellular Pathways in Skin Regeneration. BioMed Res. Int. 2015, 2015, 648108.

(21) Maquart, F. X.; Pasco, S.; Ramont, L.; Hornebeck, W.; Monboisse, J. C. An introduction to matrikines: extracellular matrixderived peptides which regulate cell activity. Implication in tumor invasion. Crit Rev. Oncol Hematol 2004, 49 (3), 199.

(22) Jose, S.; Hughbanks, M. L.; Binder, B. Y.; Ingavle, G. C.; Leach, J. K. Enhanced trophic factor secretion by mesenchymal stem/stromal cells with Glycine-Histidine-Lysine (GHK)-modified alginate hydrogels. Acta Biomater. 2014, 10 (5), 1955.

(23) Sharma, S.; Dua, A.; Malik, A. Biocompatible stimuli responsive superabsorbent polymer for controlled release of GHK-Cu peptide for wound dressing application. J. Polym. Res. 2017, 24 (7), 104.

(24) Pickart, L.; Vasquez-Soltero, J. M.; Margolina, A. The Effect of the Human Peptide GHK on Gene Expression Relevant to Nervous System Function and Cognitive Decline. Brain Sci. 2017, 7 (2), 1549.

(25) Yuan, D.; Jacquier, J. C.; O’Riordan, E. D. Entrapment of proteins and peptides in chitosan-polyphosphoric acid hydrogel beads: A new approach to achieve both high entrapment efficiency and controlled in vitro release. Food Chem. 2018, 239, 1200.

(26) Fisher, S. A.; Baker, A. E. G.; Shoichet, M. S. Designing Peptide and Protein Modified Hydrogels: Selecting the Optimal Conjugation Strategy. J. Am. Chem. Soc. 2017, 139 (22), 7416.

(27) Hynd, M. R.; Frampton, J. P.; Dowell-Mesfin, N.; Turner, J. N.; Shain, W. Directed cell growth on protein-functionalized hydrogel surfaces. J. Neurosci. Methods 2007, 162 (1-2), 255.

(28) Clapper, J. D.; Pearce, M. E.; Guymon, C. A.; Salem, A. K. Biotinylated biodegradable nanotemplated hydrogel networks for cell interactive applications. Biomacromolecules 2008, 9 (4), 1188.

(29) Arul, V.; Kartha, R.; Jayakumar, R. A therapeutic approach for diabetic wound healing using biotinylated GHK incorporated collagen matrices. Life Sci. 2007, 80 (4), 275.

(30) Granadero, D.; Bordello, J.; Perez-Alvite, M. J.; Novo, M.; AlSoufi, W. Host-guest complexation studied by fluorescence correlation spectroscopy: adamantane-cyclodextrin inclusion. Int. J. Mol. Sci. 2010, 11 (1), 173.

(31) Rodell, C. B.; Kaminski, A. L.; Burdick, J. A. Rational design of network properties in guest-host assembled and shear-thinning hyaluronic acid hydrogels. Biomacromolecules 2013, 14 (11), 4125.

(32) Holzinger, M.; Bouffier, L.; Villalonga, R.; Cosnier, S. Adamantane/beta-cyclodextrin affinity biosensors based on singlewalled carbon nanotubes. Biosens. Bioelectron. 2009, 24 (5), 1128.

(33) Liu, W. Q.; Samanta, S. K.; Smith, B. D.; Isaacs, L. Synthetic mimics of biotin/(strept)avidin. Chem. Soc. Rev. 2017, 46 (9), 2391.

(34) Savina, I. N.; Cnudde, V.; D'Hollander, S.; Van Hoorebeke, L.; Mattiasson, B.; Galaev, I. Y.; Du Prez, F. Cryogels from poly(2hydroxyethyl methacrylate): macroporous, interconnected materials with potential as cell scaffolds. Soft Matter 2007, 3 (9), 1176.

(35) Ding, L.; Li, Y.; Jia, D.; Deng, J.; Yang, W. $\beta$-Cyclodextrin-based oil-absorbents: Preparation, high oil absorbency and reusability. Carbohydr. Polym. 2011, 83 (4), 1990.

(36) Zoughaib, M. H.; Luong, D. T.; Siraeva, Z. Y.; Yergeshov, A. A.; Salikhova, T. I.; Kuznetsova, S. V.; Kiyamova, R. G.; Abdullin, T. I. Cancer cell behavior in porous hydrogel under different seeding conditions and treatment with doxorubicin. Bull. Exp. Biol. Med. 2019, 167 (4), 590.

(37) Luong, D.; Yergeshov, A. A.; Zoughaib, M.; Sadykova, F. R.; Gareev, B. I.; Savina, I. N.; Abdullin, T. I. Transition metal-doped cryogels as bioactive materials for wound healing applications. Mater. Sci. Eng., C 2019, 103, 109759.
(38) Zellander, A.; Zhao, C.; Kotecha, M.; Gemeinhart, R.; Wardlow, M.; Abiade, J.; Cho, M. Characterization of Pore Structure in Biologically Functional Poly(2-Hydroxyethyl Methacrylate) Poly(Ethylene Glycol) Diacrylate (PHEMA-PEGDA). PLoS One 2014, 9 (5), e96709.

(39) Taha, M.; Chai, F.; Blanchemain, N.; Goube, M.; Martel, B.; Hildebrand, H. F. Validating the poly-cyclodextrins based local drug delivery system on plasma-sprayed hydroxyapatite coated orthopedic implant with toluidine blue O. Mater. Sci. Eng., C 2013, 33 (5), 2639.

(40) dos Santos, J. F.; Couceiro, R.; Concheiro, A.; TorresLabandeira, J. J.; Alvarez-Lorenzo, C. Poly(hydroxyethyl methacrylate-co-methacrylated-beta-cyclodextrin) hydrogels: synthesis, cytocompatibility, mechanical properties and drug loading/release properties. Acta Biomater. 2008, 4 (3), 745-55.

(41) Yang, C.; Li, D.; Liu, Z.; Hong, G.; Zhang, J.; Kong, D.; Yang, Z. Responsive Small Molecular Hydrogels Based on AdamantanePeptides for Cell Culture. J. Phys. Chem. B 2012, 116 (1), 633.

(42) Zustiak, S. P.; Pubill, S.; Ribeiro, A.; Leach, J. B. Hydrolytically Degradable Poly(ethylene glycol) Hydrogel Scaffolds as a Cell Delivery Vehicle: Characterization of PC12 Cell Response. Biotechnol. Prog. 2013, 29 (5), 1255-1264.

(43) Gharib, R.; Auezova, L.; Charcosset, C.; Greige-Gerges, H. Drug-in-cyclodextrin-in-liposomes as a carrier system for volatile essential oil components: Application to anethole. Food Chem. 2017, $218,365$.

(44) Başbağ, A. B.; Gümüşderelioğlu, M.; Şimşek, M.; Güner, A. Poly(HEMA)/cyclodextrin-based hydrogels for subconjunctival delivery of cyclosporin A. J. Appl. Polym. Sci., 2014, 131 (12), DOI: 10.1002/app.40397.

(45) Liu, S.; Chen, X.; Zhang, Q.; Wu, W.; Xin, J.; Li, J. Multifunctional hydrogels based on beta-cyclodextrin with both biomineralization and anti-inflammatory properties. Carbohydr. Polym. 2014, 102, 869.

(46) Demir, S.; Kahraman, M. V.; Bora, N.; Kayaman Apohan, N.; Ogan, A. Preparation, characterization, and drug release properties of poly(2-hydroxyethyl methacrylate) hydrogels having beta-cyclodextrin functionality. J. Appl. Polym. Sci. 2008, 109 (2), 1360.

(47) Stimac, A.; Sekutor, M.; Mlinaric-Majerski, K.; Frkanec, L.; Frkanec, R. Adamantane in Drug Delivery Systems and Surface Recognition. Molecules 2017, 22 (2), 297.

(48) Guo, X.; Wang, J.; Li, L.; Pham, D.-T.; Clements, P.; Lincoln, S. F.; May, B. L.; Chen, Q.; Zheng, L.; Prud'homme, R. K. Tailoring Polymeric Hydrogels through Cyclodextrin Host-Guest Complexation. Macromol. Rapid Commun. 2010, 31 (3), 300.

(49) Teesalu, T.; Sugahara, K. N.; Ruoslahti, E. Mapping of vascular ZIP codes by phage display. Methods Enzymol. 2012, 503, 35.

(50) Garifullin, R.; Ustahuseyin, O.; Celebioglu, A.; Cinar, G.; Uyar, T.; Guler, M. O. Noncovalent functionalization of a nanofibrous network with a bio-inspired heavy metal binding peptide. RSC Adv. 2013, 3 (46), 24215.

(51) Bai, Y.; Englander, S. W. Hydrogen bond strength and $\beta$-sheet propensities: The role of a side chain blocking effect. Proteins: Struct., Funct., Genet. 1994, 18 (3), 262.

(52) Philip, D. L.; Silantyeva, E. A.; Becker, M. L.; Willits, R. K. RGD-Functionalized Nanofibers Increase Early GFAP Expression during Neural Differentiation of Mouse Embryonic Stem Cells. Biomacromolecules 2019, 20 (3), 1443.

(53) Hern, D. L.; Hubbell, J. A. Incorporation of adhesion peptides into nonadhesive hydrogels useful for tissue resurfacing. J. Biomed. Mater. Res. 1998, 39 (2), 266.

(54) Hahn, M. S.; Taite, L. J.; Moon, J. J.; Rowland, M. C.; Ruffino, K. A.; West, J. L. Photolithographic patterning of polyethylene glycol hydrogels. Biomaterials 2006, 27 (12), 2519.

(55) Feijão, T.; Torres, A. L.; Araújo, M.; Barrias, C. C., Chapter20 Peptide-Modified Hydrogels for Therapeutic Vascularization, in Biomedical Applications of Functionalized Nanomaterials; Sarmento, B., das Neves, J., Eds.; Elsevier: 2018; pp 599-620.

(56) Badea, A.; McCracken, J. M.; Tillmaand, E. G.; Kandel, M. E.; Oraham, A. W.; Mevis, M. B.; Rubakhin, S. S.; Popescu, G.; Sweedler, 
J. V.; Nuzzo, R. G. 3D-Printed pHEMA Materials for Topographical and Biochemical Modulation of Dorsal Root Ganglion Cell Response. ACS Appl. Mater. Interfaces 2017, 9 (36), 30318-30328.

(57) Ali, S.; Saik, J. E.; Gould, D. J.; Dickinson, M. E.; West, J. L. Immobilization of Cell-Adhesive Laminin Peptides in Degradable PEGDA Hydrogels Influences Endothelial Cell Tubulogenesis. BioRes. Open Access 2013, 2 (4), 241. 